\title{
Bacterial growth tolerance to concentrations of chlorate and perchlorate salts relevant to Mars
}

\author{
Amer F. Al Soudi', Omar Farhat', Fei Chen ${ }^{2}$, Benton C. Clark ${ }^{3}$ and \\ Mark A. Schneegurt' \\ ${ }^{1}$ Department of Biological Sciences, Wichita State University, Wichita, KS, USA e-mail: mark.schneegurt@wichita.edu \\ ${ }^{2}$ Jet Propulsion Laboratory, Pasadena, CA, USA \\ ${ }^{3}$ Space Science Institute, Boulder, CO, USA
}

\begin{abstract}
The Phoenix lander at Mars polar cap found appreciable levels of (per)chlorate salts, a mixture of perchlorate and chlorate salts of $\mathrm{Ca}, \mathrm{Fe}, \mathrm{Mg}$ and $\mathrm{Na}$ at levels of $\sim 0.6 \%$ in regolith. These salts are highly hygroscopic and can form saturated brines through deliquescence, likely producing aqueous solutions with very low freezing points on Mars. To support planetary protection efforts, we have measured bacterial growth tolerance to (per)chlorate salts. Existing bacterial isolates from the Great Salt Plains of Oklahoma ( NaCl-rich) and Hot Lake in Washington $\left(\mathrm{MgSO}_{4}\right.$-rich) were tested in high concentrations of $\mathrm{Mg}, \mathrm{K}$ and $\mathrm{Na}$ salts of chlorate and perchlorate. Strong growth was observed with nearly all of these salinotolerant isolates at $1 \%(\sim 0.1 \mathrm{M})$ (per)chlorate salts, similar to concentrations observed in bulk soils on Mars. Growth in perchlorate salts was observed at concentrations of at least $10 \%(\sim 1.0 \mathrm{M})$. Greater tolerance was observed

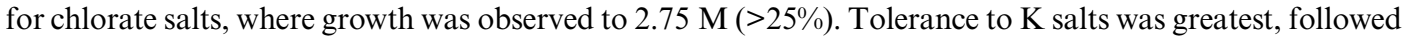
by $\mathrm{Mg}$ salts and then $\mathrm{Na}$ salts. Tolerances varied among isolates, even among those within the same phylogenetic clade. Tolerant bacteria included genera that also are found in spacecraft assembly facilities. Substantial microbial tolerance to (per)chlorate salts is a concern for planetary protection since tolerant microbes contaminating spacecraft would have a greater chance for survival and proliferation, despite the harsh chemical conditions found near the surface of Mars.

Received 5 August 2016, accepted 6 October 2016, first published online 22 November 2016
\end{abstract}

Key words: chlorate, extremophiles, growth tolerance, Mars, perchlorate, planetary protection.

\section{Introduction}

Oxyanions of chlorine have been detected on the surface of Mars (Hecht et al. 2009; Kounaves et al. 2010; Ming et al. 2014; Clark \& Kounaves 2015). The Phoenix lander at Mars' polar region measured levels of $\sim 0.4-0.6 \%$ in regolith that represent chlorate and perchlorate salts and perhaps other oxychlorines. (Per)Chlorate also has been detected at the Curiosity landing site and in Moon and meteorite samples (Glavin et al. 2013; Jackson et al. 2015b). Common cations include calcium, iron, magnesium and sodium (Kounaves et al. 2014; Ming et al. 2014). While their planetary distribution is uneven, chloride and (per)chlorate salts are widespread (Clark \& Kounaves 2015). The (per)chlorate salts are highly hygroscopic and therefore have relevance to astrobiology studies of Mars. There is reason to believe that enough humidity exists in the atmosphere of Mars to create deliquescent brines through absorption of water by (per)chlorate salts (Chevrier et al. 2009; MartínTorres et al. 2015; Ojha et al. 2015). Equally as important is the fact that brines of (per)chlorate salts have very low eutectic temperatures, some remaining liquid even to below $-70^{\circ} \mathrm{C}$ (Möhlmann \& Thomsen 2011; Clark \& Kounaves 2015).

The intense aridity and extremely low temperatures at the Martian surface create environmental conditions particularly challenging to organisms. It has been suggested that (per) chlorate salts may be important sources of liquid water in the Martian near surface (Zorzano et al. 2009; Davila et al. 2010; Nuding et al. 2014). Spectral evidence is consistent with the idea that recurring slope lineae result from brines of $\mathrm{Mg}$ perchlorate, $\mathrm{Mg}$ chlorate and $\mathrm{Na}$ perchlorate (Ojha et al. 2015). Strong oxidants, such as oxychlorines, are typically incompatible with living systems. However, due to mechanistic kinetic barriers, (per)chlorate salts are quite stable in aqueous environments and are not easily reduced (Urbansky 1998; Gu et al. 2003).

Perchlorate salts on the Earth tend to result from industrial processes that produce explosives, herbicides, lubricants, paints and paper (Motzer 2001; Urbansky 2002). These salts can contaminate drinking water and be toxic to humans, through competition with iodine in the thyroid (Hooth et al. 2001; Kalkhoff et al. 2010; EPA 2011). Natural perchlorate salts have been detected in the very arid regions of the Atacama Desert and Antarctica (Kounaves et al. 2010; Jackson et al. 2015a). This includes Chilean nitrate deposits, which have levels of perchlorate approaching $0.6 \%$ (Ericksen 1981). Trace levels of perchlorate salts have been detected in a variety of other aqueous and soil environments (Smith 
et al. 2004; Rajagopalan et al. 2006, 2009; Rao et al. 2007). Given the rarity of these salts worldwide, it might be expected that growth tolerances to high concentrations of (per)chlorate would be rare among microorganisms.

An early study by Durand (1938) found appreciable microbial growth tolerance to $\mathrm{Na}$ perchlorate. Bacterium coli (Escherichia coli) grew in the presence of $2.5 \%(\sim 0.25 \mathrm{M}) \mathrm{Na}$ perchlorate and Staphylococcus pyogenes aureus ( $S$. aureus), showed slow growth in the presence of $7.5 \%(\sim 0.75 \mathrm{M})$, but no growth at $10 \%(\sim 1.0 \mathrm{M})$, Na perchlorate. Sterigmatocystis nigra (Aspergillus niger) exhibited strong mycelial growth at $1 \%(\sim 0.1 \mathrm{M}) \mathrm{Na}$ perchlorate and approximately $25 \%$ as much growth at $4 \%(\sim 0.4 \mathrm{M}) \mathrm{Na}$ perchlorate. A recent preliminary report suggests that the haloarchaeon Haloarcula argentinensis can grow in the presence of $0.5 \mathrm{M}(\sim 5 \%)$ perchlorate, even in medium containing $15 \%(\sim 3.0 \mathrm{M}) \mathrm{NaCl}$ (Thombre et al. 2015). A study of halotolerant Haloarcula, Haloferax and Halomonas demonstrated strong growth in the presence of $0.4 \mathrm{M}$ Na perchlorate, with weak growth of Haloferax at $0.6 \mathrm{M}$ (Oren et al. 2014). Two other recent studies examine another clade of Archaea. Methanogenesis was demonstrated to proceed in the presence of $1 \%$ perchlorate, but no higher, for strains of Methanobacterium, Methanosarcina and Methanothermobacter (Kral et al. 2016). However, when adapted to higher concentrations of perchlorate salts, these methanogens appeared to metabolize despite the presence of up to $5 \%$ (but not $10 \%$ ) perchlorate. A similar study with Methanobacterium and Methanosarcina isolates from permafrost observed methanogenesis only at very much lower concentrations of $\mathrm{Mg}$ and $\mathrm{Na}$ perchlorates, $0.1 \%(\sim 10 \mathrm{mM})$ or less (Shcherbakova et al. 2015). Another previous study with a facultative anaerobic consortium did not detect growth at $0.4 \%$ perchlorate (Bardiya \& Bae 2005).

There is a substantial body of literature on microbes that can use perchlorate as a terminal electron acceptor for anaerobic respiration (Wallace et al. 1996, 1998; Coates et al. 1999; Herman \& Frankenberger 1999; Okeke et al. 2002; Coates \& Achenbach 2004; Shete et al. 2008). Typically perchlorate is added to media at concentrations below $1 \mathrm{mM}$. The biological reduction of perchlorate is performed by perchlorate reductase, producing a chlorite anion, which is toxic to cells if not further reduced to chloride. It has been suggested that microorganisms with nitrate reductase can convert perchlorate into chlorite, but that this is then cytotoxic. Certainly (per)chlorate respiration has clear astrobiology relevance given that (per)chlorate brines may be present on Mars. However, perchlorate respirers would still need to be tolerant to very high concentrations of (per) chlorate salts.

Microbes exhibiting high tolerance to (per)chlorate anion also need to be tolerant of high concentrations of the accompanying cations. We have examined (per)chlorate growth tolerance in bacteria isolated from hypersaline environments, including terrestrial hyperhaline soils rich in $\mathrm{NaCl}$ from the Great Salt Plains of Oklahoma and epsomite lake margins and sediments rich in $\mathrm{MgSO}_{4}$ from Hot Lake in Washington. Our study has relevance to potential forward contamination of (per)chlorate brines on Mars by spacecraft carrying soil
Table 1. Salinotolerant bacteria used for this study from Hot Lake (Kilmer et al. 2014) and the Great Salt Plains (Caton et al. 2004)

\begin{tabular}{lll}
\hline Isolate & Identification & GenBank accession \\
\hline HL11 & Marinococcus halophilus & KC705247 \\
HL12 & Halomonas venusta & KC705248 \\
HL14 & Halomonas venusta & KC705250 \\
HL20 & Planococcus maritimus & KC705257 \\
HL54 & Marinococcus halophilus & KC705293 \\
HL55 & Bacillus licheniformis & KC705294 \\
HL64 & Nesterenkonia halotolerans & KC705304 \\
HL68 & Bacillus licheniformis & KC705308 \\
HL76 & Nesterenkonia halotolerans & KC705317 \\
HL80 & Planococcus salinarum & KC705322 \\
HL82 & Halomonas venusta & KC705324 \\
HL91 & Planococcus salinarum & KC705334 \\
GSP3 & Halomonas venusta & AY505527 \\
GSP10 & Bacillus megaterium & AY505510 \\
GSP11 & Terribacillus halophilus & AY553069 \\
GSP17 & Salibacillus marismortui & AY505533 \\
GSP21 & Halomonas salina & AY553072 \\
GSP63 & Bacillus licheniformis & AY553106 \\
\hline
\end{tabular}

particles or the salinotolerant bacteria commonly found in spacecraft assembly facilities (SAF).

\section{Materials and methods}

\section{Organisms}

Bacterial isolate collections previously generated from hypersaline environments were used to measure growth tolerances. We previously characterized 93 halotolerant aerobic heterotrophic bacteria isolated from the Great Salt Plains of Oklahoma, a wet terrestrial environment saturated with $\mathrm{NaCl}$ (Caton et al. 2004). Similar work at Hot Lake, WA, an environment saturated with $\mathrm{MgSO}_{4}$ (epsomite), yielded a collection of 64 bacterial isolates from sediments and lake margin samples (Kilmer et al. 2014). A group of 18 isolates from these collections was chosen for further study based on salinotolerance and taxonomy (Table 1).

\section{Media and growth measurements}

Bacterial cultures were grown on Salt Plains (SP) medium supplemented with various (per)chlorate salts (Caton et al. 2004). Shake tubes $(2 \mathrm{ml}$ in $13 \times 100 \mathrm{~mm}$ tubes) were lightly loopinoculated in triplicate (below 0.05 OD units) from agar slants and maintained at room temperature on a rotary shaker (150 rpm, 1-in stroke dia). Culture density was determined as $A_{600}$ by spectrophotometry (ThermoFisher Genesys 10S) using a medium blank at the time of inoculation and at 2 days intervals for 12 days after inoculation. Error bars of SD were generally smaller than the symbols used for plotting growth curves.

The water activity of each medium (Table 2) was measured using an AqualLab Series 3 water activity meter (Decagon Devices, Inc., Pullman, WA). The instrument was calibrated with standard $\mathrm{NaCl}$ solutions and run at room temperature. 
Table 2. Water activities of (per) chlorate salt solutions

\begin{tabular}{ll}
\hline Solute & $a_{\mathrm{w}}$ \\
\hline $0.1 \mathrm{M} \mathrm{NaClO}_{3}$ & 0.99 \\
$0.5 \mathrm{M} \mathrm{NaClO}_{3}$ & 0.98 \\
$1.0 \mathrm{M} \mathrm{NaClO}_{3}$ & 0.96 \\
$1.5 \mathrm{M} \mathrm{NaClO}_{3}$ & 0.94 \\
$2.0 \mathrm{M} \mathrm{NaClO}_{3}$ & 0.91 \\
$2.75 \mathrm{M} \mathrm{NaClO}_{3}$ & 0.89 \\
$0.1 \mathrm{M} \mathrm{KClO}_{3}$ & 0.99 \\
$0.5 \mathrm{M} \mathrm{KClO}_{3}$ & 0.98 \\
$1.0 \mathrm{M} \mathrm{KClO}_{3}$ & 0.98 \\
$0.1 \mathrm{M} \mathrm{NaClO}_{4}$ & 0.99 \\
$0.5 \mathrm{M} \mathrm{NaClO}_{4}$ & 0.98 \\
$1.0 \mathrm{M} \mathrm{NaClO}_{4}$ & 0.96 \\
$0.1 \mathrm{M} \mathrm{KClO}_{4}$ & 0.99 \\
$0.5 \mathrm{M} \mathrm{KClO}_{4}$ & 0.98 \\
$1.0 \mathrm{M} \mathrm{KClO}_{4}$ & 0.97 \\
$0.05 \mathrm{M} \mathrm{Mg}_{4}\left(\mathrm{ClO}_{4}\right)_{2}$ & 0.99 \\
$0.25 \mathrm{M} \mathrm{Mg}_{2}\left(\mathrm{ClO}_{4}\right)_{2}$ & 0.98 \\
$\left.0.5 \mathrm{M} \mathrm{Mg}_{2} \mathrm{ClO}_{4}\right)_{2}$ & 0.97 \\
\hline
\end{tabular}

\section{(Per)chlorate measurements}

Chlorate and perchlorate concentrations were measured by ion chromatography as previously described (Carlström et al. 2015). Briefly, a mobile phase of $36 \mathrm{mM} \mathrm{NaOH}$ was used with a Dionex Ion Pac AS 25 column $(4 \times 250 \mathrm{~mm})$ in a Dionex ICS 500 instrument in recycle mode with a Dionex ASRS $300(4 \mathrm{~mm})$ and suppressor control at $90 \mathrm{~mA}$. Samples of culture media were clarified by filtration $(0.22 \mu \mathrm{m})$ before dilution and analysis.

\section{Results}

\section{Growth tolerance to perchlorate salts}

Growth tolerances to high concentrations of (per)chlorate salts were determined for 18 salinotolerant bacterial isolates. Tests were performed at several concentrations of $\mathrm{Mg}$, $\mathrm{K}$ and Na perchlorate salts and with $\mathrm{K}$ and $\mathrm{Na}$ chlorate salts. Representative growth curves are presented for HL12, a Halomonas venusta isolate from Hot Lake, which was particularly tolerant to (per) chlorate exposure (Figs. 1-3).

Magnesium perchlorate is a likely Mars salt and is a major contributor to the $\sim 0.6 \%(\sim 0.06 \mathrm{M})$ level of (per)chlorate salts observed by Phoenix (Hecht et al. 2009). Growth of HL12 in the presence of $0.05 \mathrm{M}(\sim 1 \%) \mathrm{Mg}$ perchlorate was rapid and robust (Fig. 1). Growth in the presence of $0.25 \mathrm{M}$ $(\sim 5 \%) \mathrm{Mg}$ perchlorate was slower and the cultures did not become as dense as those cultures grown with $0.05 \mathrm{M} \mathrm{Mg}$ perchlorate. The small amount of growth that HL12 may have exhibited in medium supplemented with $0.5 \mathrm{M} \mathrm{Mg}$ perchlorate was near the threshold that was chosen for faint growth ( 0.1 OD unit). All of the salinotolerant isolates grew robustly in the presence of $0.05 \mathrm{M} \mathrm{Mg}$ perchlorate, except HL 54 and 82 (Table 3). Half of the isolates exhibited positive growth in the presence $0.25 \mathrm{M} \mathrm{Mg}$ perchlorate. While some growth may have occurred at levels as high as $0.5 \mathrm{M}(\sim 10 \%) \mathrm{Mg}$ perchlorate for certain isolates, it was limited and inconsistent.

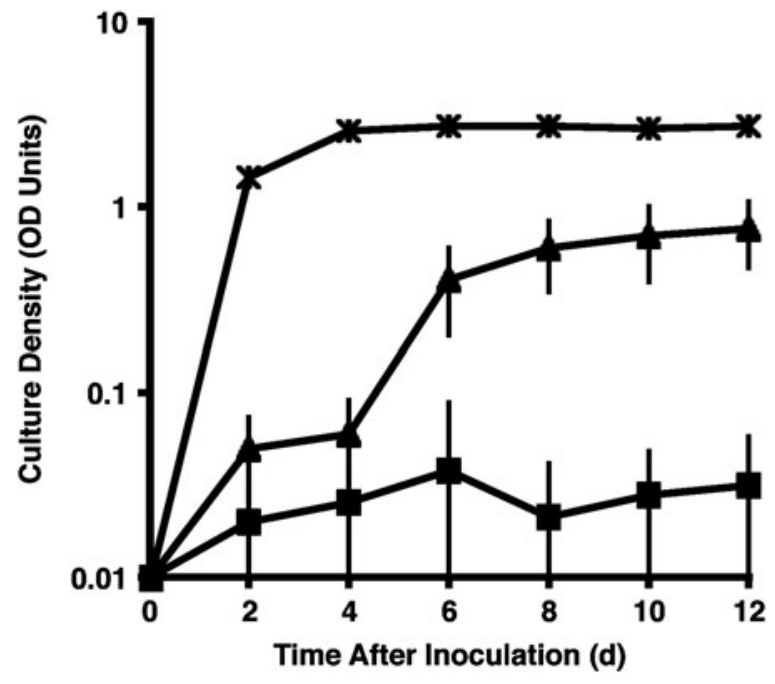

Fig. 1. Growth of HL12 in SP medium supplemented with $\mathrm{Mg}$ perchlorate. Bacterial growth in shake-tube cultures was measured by turbidity and is presented in OD units. SD of some triplicate cultures were smaller than the point markers. Stars, $0.05 \mathrm{M} \mathrm{Mg}$ perchlorate; triangles, $0.25 \mathrm{M} \mathrm{Mg}$ perchlorate; squares, $0.5 \mathrm{M} \mathrm{Mg}$ perchlorate.

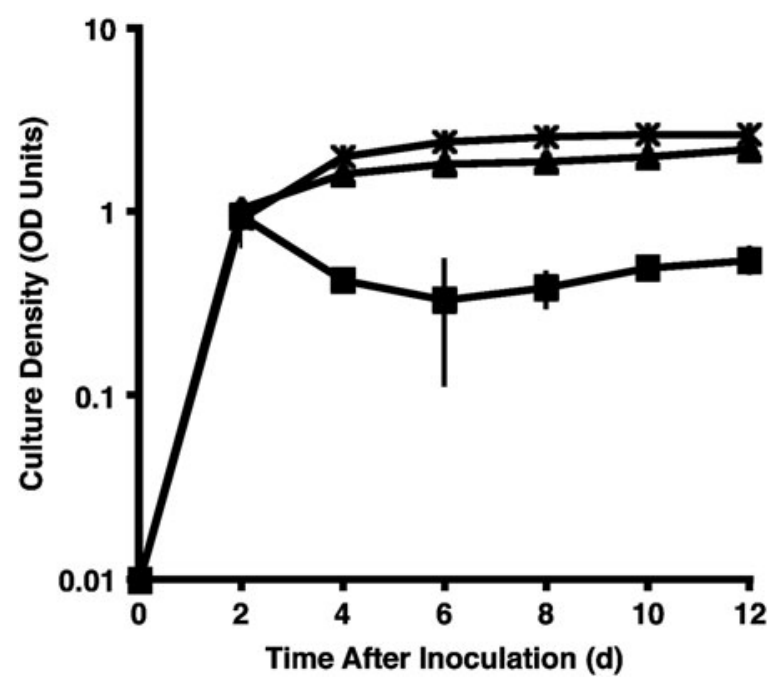

Fig. 2. Growth of HL12 in SP medium supplemented with $\mathrm{Na}$ perchlorate. Bacterial growth in shake-tube cultures was measured by turbidity and is presented in OD units. SD of some triplicate cultures were smaller than the point markers. Stars, 0.1 M Na perchlorate; triangles, 0.5 M Na perchlorate; squares, 1.0 M Na perchlorate.

Growth of HL12 was robust in the presence of 0.1 and $0.5 \mathrm{M}$ Na perchlorate (Fig. 2). At $1.0 \mathrm{M}$ Na perchlorate, growth was slower and the maximum density reached was $<30 \%$ of that attained in the presence $0.5 \mathrm{M} \mathrm{Na}$ perchlorate. Only HL12 showed substantial growth at $1.0 \mathrm{M} \mathrm{Na}$ perchlorate. HL11, 12 and 55 grew robustly with $0.5 \mathrm{M} \mathrm{Na}$ perchlorate. Overall, 12 of 18 isolates showed growth in $0.5 \mathrm{M}$ Na perchlorate. All showed robust growth at $0.1 \mathrm{M}$ Na perchlorate, except for HL82.

HL12 showed robust growth in the presence of K perchlorate at $\leq 1.0 \mathrm{M}$ (Fig. 3). The growth tolerance of HL12 to the 


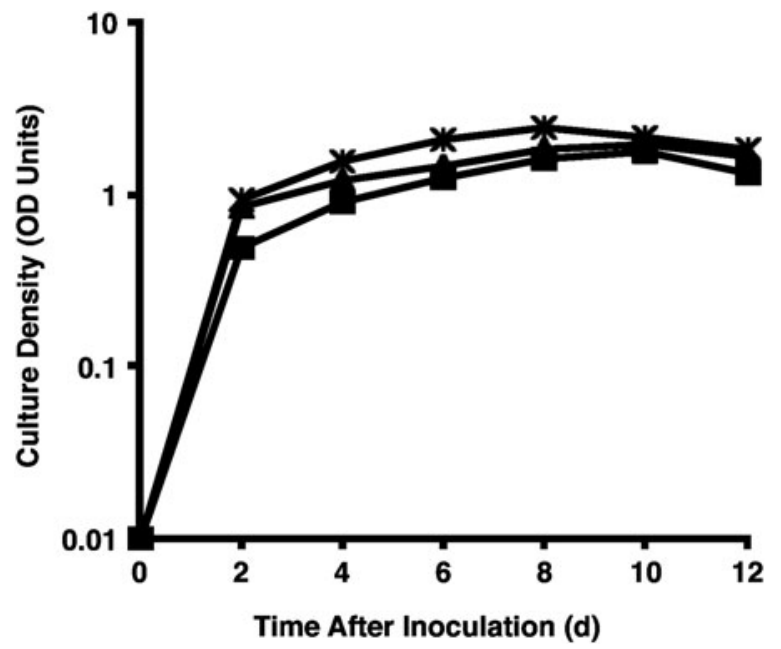

Fig. 3. Growth of HL12 in SP medium supplemented with K perchlorate. Bacterial growth in shake-tube cultures was measured by turbidity and is presented in OD units. SD of triplicate cultures were smaller than the point markers. Stars, $0.1 \mathrm{M} \mathrm{K}$ perchlorate; triangles, $0.5 \mathrm{M}$ K perchlorate; squares, 1.0 M K perchlorate.

Table 3. Maximum culture density (OD units) observed for salinotolerant bacterial isolates grown in the presence of perchlorate salts

\begin{tabular}{|c|c|c|c|c|c|c|c|c|c|}
\hline \multirow[b]{3}{*}{ Isolate } & \multicolumn{9}{|c|}{ Solute concentration $(\mathrm{M})$} \\
\hline & \multicolumn{3}{|c|}{ Na perchlorate } & \multicolumn{3}{|c|}{ Mg perchlorate } & \multicolumn{3}{|c|}{$\mathrm{K}$ perchlorate } \\
\hline & 0.1 & 0.5 & 1.0 & 0.05 & 0.25 & 0.5 & 0.1 & 0.5 & 1.0 \\
\hline HL11 & 2.52 & 2.09 & 0.04 & 2.62 & 0.14 & 0.05 & 1.55 & 1.26 & 0.38 \\
\hline HL12 & 2.63 & 2.21 & 0.60 & 2.69 & 1.09 & 0.05 & 1.81 & 1.48 & 1.22 \\
\hline HL14 & 2.65 & 0.07 & 0.04 & 1.92 & 0.01 & 0.04 & 1.26 & 1.09 & 1.08 \\
\hline HL20 & 1.90 & 0.01 & 0.09 & 2.42 & 0.21 & 0.08 & 0.84 & 0.06 & 0.01 \\
\hline HL54 & 2.02 & 0.22 & 0.08 & 0.69 & 0.11 & 0.06 & 1.78 & 1.12 & 1.31 \\
\hline HL55 & 2.33 & 0.98 & 0.09 & 1.84 & 0.62 & 0.05 & 1.24 & 1.15 & 1.10 \\
\hline HL64 & 2.48 & 0.03 & 0.10 & 2.56 & 0.30 & 0.06 & 1.88 & 1.46 & 1.17 \\
\hline HL68 & 2.56 & 0.45 & 0.09 & 2.25 & 0.57 & 0.05 & 0.98 & 0.62 & 0.02 \\
\hline HL76 & 2.54 & 0.02 & 0.10 & 2.64 & 0.04 & 0.15 & 1.19 & 0.34 & 0.02 \\
\hline HL80 & 2.66 & 0.01 & 0.09 & 1.74 & 0.02 & 0.01 & 2.13 & 1.23 & 0.72 \\
\hline HL82 & 0.05 & 0.04 & 0.10 & 0.01 & 0.02 & 0.03 & 1.12 & 1.05 & 1.08 \\
\hline HL91 & 1.30 & 0.50 & 0.09 & 1.94 & 0.64 & 0.11 & 1.54 & 1.14 & 1.01 \\
\hline GSP3 & 1.35 & 0.37 & 0.09 & 2.47 & 0.08 & 0.11 & 2.12 & 1.32 & 0.09 \\
\hline GSP10 & 1.63 & 0.15 & 0.09 & 2.18 & 0.03 & 0.03 & 1.63 & 0.15 & 0.07 \\
\hline GSP11 & 1.29 & 0.42 & 0.09 & 1.76 & 0.03 & 0.32 & 2.15 & 1.12 & 1.09 \\
\hline GSP17 & 1.44 & 0.35 & 0.09 & 2.14 & 0.10 & 0.30 & 1.02 & 0.98 & 0.43 \\
\hline GSP21 & 1.71 & 0.16 & 0.09 & 2.19 & 0.05 & 0.07 & 1.71 & 1.32 & 1.02 \\
\hline GSP63 & 1.54 & 0.80 & 0.09 & 1.96 & 0.04 & 0.07 & 1.04 & 0.50 & 0.01 \\
\hline
\end{tabular}

$\mathrm{K}$ salt was substantially greater at $1.0 \mathrm{M}$ than was growth tolerance to the corresponding $\mathrm{Mg}$ or $\mathrm{Na}$ salts. The salinotolerant isolates overall performed better in the presence of $\mathrm{K}$ perchlorate than with $\mathrm{Mg}$ or $\mathrm{Na}$ perchlorate (Table 3). More than half of the isolates grew well in the presence of $1.0 \mathrm{M} \mathrm{K}$ perchlorate, while growth in $\mathrm{Mg}$ and $\mathrm{Na}$ salts at $1 \mathrm{M}$ perchlorate was barely detectable. All of the isolates grew well at $0.1 \mathrm{M} \mathrm{K}$ perchlorate and only HL20 and GSP10 did not grow well at $0.5 \mathrm{M} \mathrm{K}$ perchlorate. The solubilities of calcium and iron perchlorate salts in media were too low $(<0.1 \mathrm{M})$ for meaningful growth tolerance experiments.
Table 4. Maximum culture density (OD units) observed for salinotolerant bacterial isolates grown in the presence of chlorate salts

\begin{tabular}{|c|c|c|c|c|c|c|c|c|c|}
\hline \multirow[b]{3}{*}{ Isolate } & \multicolumn{9}{|c|}{ Solute concentration (M) } \\
\hline & \multicolumn{6}{|c|}{ Na chlorate } & \multicolumn{3}{|c|}{ K chlorate } \\
\hline & 0.1 & 0.5 & 1.0 & 1.5 & 2.0 & 2.75 & 0.1 & 0.5 & 1.0 \\
\hline HL11 & 2.34 & 2.48 & 2.18 & 2.29 & 1.65 & 1.62 & 2.54 & 2.32 & 2.38 \\
\hline HL12 & 1.95 & 2.30 & 2.16 & 2.03 & 1.81 & 1.81 & 2.46 & 2.08 & 1.03 \\
\hline HL14 & 1.39 & 1.57 & 0.76 & 0.03 & 0.24 & 0.15 & 2.02 & 1.98 & 1.08 \\
\hline HL20 & 1.87 & 1.67 & 1.63 & 0.06 & 0.06 & 0.06 & 0.98 & 0.87 & 0.89 \\
\hline HL54 & 0.28 & 0.74 & 0.38 & 0.11 & 0.10 & 0.07 & 2.00 & 1.54 & 1.21 \\
\hline HL55 & 1.42 & 1.40 & 1.18 & 0.49 & 0.05 & 0.04 & 1.87 & 1.73 & 1.54 \\
\hline HL64 & 2.25 & 2.55 & 0.62 & 0.58 & 0.07 & 0.06 & 2.43 & 2.31 & 2.21 \\
\hline HL68 & 1.02 & 1.59 & 1.10 & 0.46 & 0.05 & 0.07 & 1.27 & 1.06 & 0.99 \\
\hline HL76 & 2.22 & 2.41 & 0.76 & 1.13 & 0.09 & 0.08 & 2.99 & 2.06 & 2.01 \\
\hline HL80 & 1.80 & 1.81 & 0.04 & 0.04 & 0.11 & 0.11 & 0.79 & 0.52 & 0.43 \\
\hline HL82 & 0.01 & 0.06 & 0.06 & 0.02 & 0.06 & 0.06 & 0.18 & 0.14 & 0.08 \\
\hline HL91 & 0.82 & 1.72 & 1.01 & 0.73 & 0.05 & 0.03 & 1.07 & 0.98 & 0.87 \\
\hline GSP3 & 1.38 & 2.27 & 1.58 & 0.81 & 0.14 & 0.14 & 1.21 & 0.93 & 0.97 \\
\hline GSP10 & 2.05 & 1.97 & 1.51 & 1.12 & 0.05 & 0.04 & 1.03 & 0.93 & 0.97 \\
\hline GSP11 & 1.38 & 2.24 & 1.69 & 1.61 & 0.21 & 0.21 & 1.75 & 1.62 & 1.09 \\
\hline GSP17 & 1.38 & 1.99 & 0.97 & 1.49 & 0.30 & 0.22 & 1.65 & 1.43 & 1.23 \\
\hline GSP21 & 1.33 & 1.94 & 1.54 & 1.46 & 0.39 & 0.39 & 1.87 & 1.84 & 1.66 \\
\hline GSP63 & 1.37 & 2.11 & 0.77 & 1.30 & 0.18 & 0.18 & 2.08 & 2.01 & 1.98 \\
\hline
\end{tabular}

\section{Growth tolerance to chlorate salts}

Growth tolerances to chlorate salts were greater among the isolates than were growth tolerances to perchlorate salts ( $c f$. Tables 3 and 4). All of the isolates grew robustly in the presence of $0.1 \mathrm{M} \mathrm{Na}$ chlorate, except HL 54 and 82 (Table 4). This trend continued up to $1.0 \mathrm{M} \mathrm{Na}$ chlorate, and in medium with $1.5 \mathrm{M}$ Na chlorate, 13 of 18 isolates grew well. At 2.75 $\mathrm{M}(\sim 25 \%)$ Na chlorate, HL 11 and 12 showed strong growth, while several other isolates exhibited weak growth. Note that none of the isolates grew strongly in $1 \mathrm{M}$ perchlorate salts. Growth curves for HL12 at different concentrations of $\mathrm{Na}$ chlorate show that, for the highest concentrations tested, lag phases were longer, growth rates were slower, and maximum culture densities were lower (Fig. 4). However, growth was still substantial even at $2.75 \mathrm{M}$ Na chlorate, the highest concentration at which media could be prepared without visible precipitate. In the presence of $1.0 \mathrm{M} \mathrm{K}$ chlorate, growth was strong for all isolates, except HL 80 and 82 (Table 4), with this being the highest concentration that could be added to culture medium without visible precipitate. HL12 grew robustly in the presence of 0.1 or $0.5 \mathrm{M} \mathrm{K}$ chlorate, but growth was slowed, although still strong, at $1.0 \mathrm{M} \mathrm{K}$ chlorate (Fig. 5). Tolerance to $\mathrm{K}$ chlorate was not consistently greater than to $\mathrm{Na}$ chlorate, in contrast to the corresponding perchlorate salts. We were unable to obtain $\mathrm{Ca}$ or $\mathrm{Mg}$ chlorate commercially to complete the iterative matrix of salts. The solubility of iron chlorate in media was too low $(<0.1 \mathrm{M})$ for meaningful growth tolerance experiments.

\section{(Per) chlorate retention by cultures}

While it appears that these salinotolerant bacterial isolates can grow in the presence of high concentrations of (per)chlorate salts, it was possible that the microbes detoxify the anions, 


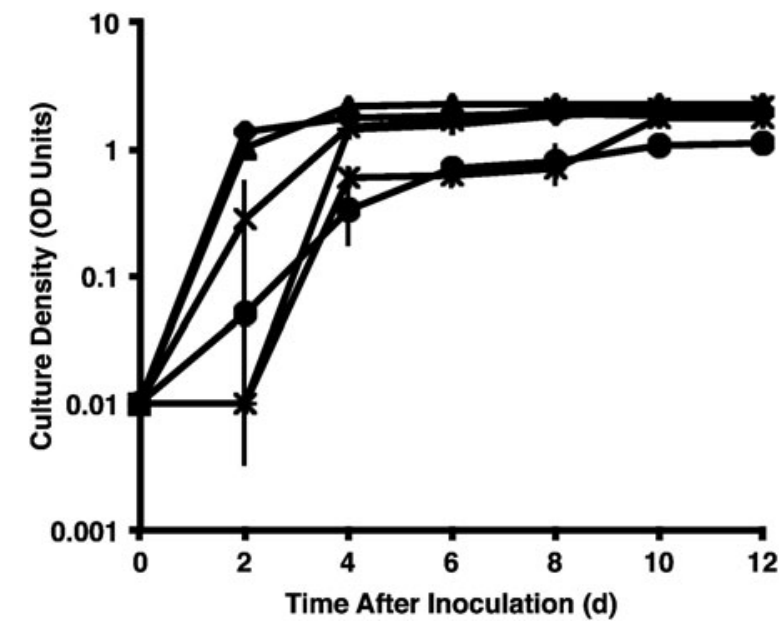

Fig. 4. Growth of HL12 in SP medium supplemented with $\mathrm{Na}$ chlorate. Bacterial growth in shake-tube cultures was measured by turbidity and is presented in OD units. SD of some triplicate cultures were smaller than the point markers. Diamonds, $0.1 \mathrm{M}$ Na chlorate; triangles, $0.5 \mathrm{M}$ Na chlorate; $\mathrm{X}, 1.0 \mathrm{M} \mathrm{Na}$ chlorate; +, 1.5 M Na chlorate; stars, 2.0 M Na chlorate; circles, $2.5 \mathrm{M} \mathrm{Na}$ chlorate.

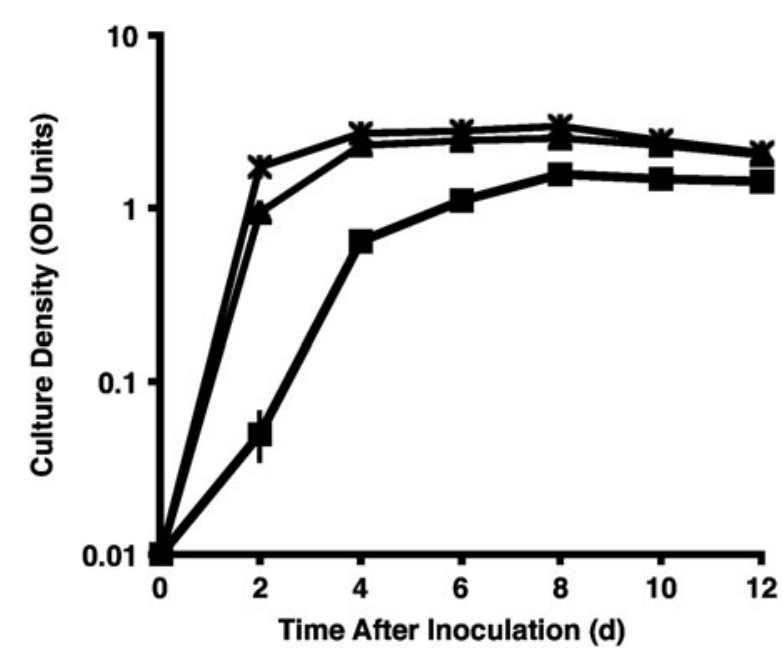

Fig. 5. Growth of HL12 in SP medium supplemented with K chlorate. Bacterial growth in shake-tube cultures was measured by turbidity and is presented in OD units. SD of triplicate cultures were smaller than the point markers. Stars, $0.1 \mathrm{M} \mathrm{K}$ chlorate; triangles, $0.5 \mathrm{M} \mathrm{K}$ chlorate; squares, 1.0 M K chlorate.

removing them before substantially growing. Chlorate and perchlorate levels were measured by ion-exchange chromatography before and after microbial cultivation. Overall there were only small differences between the (per)chlorate concentrations of media before and after cultivation. For example, in medium containing $0.25 \mathrm{M} \mathrm{Mg}$ perchlorate, there was less than a $2 \%$ difference between the initial concentration of perchlorate and the concentration of perchlorate after the growth of HL12 in batch culture. Similarly, for medium containing $0.5 \mathrm{M}$ Na chlorate, there was less than a $2 \%$ change in chlorate concentration after batch culture of HL12. Tests with other cations, isolates and concentrations gave the same general outcome. In addition, no appreciable chlorate was present after bacterial cultivation in any medium initially containing perchlorate. Perchlorate respiration is an anaerobic process and it does not appear that (per) chlorate was metabolized in our aerobic cultures. (Per)Chlorate added to the medium remained at high concentrations throughout the development of the microbial culture.

\section{Discussion}

The ability to grow in the presence of $0.1 \mathrm{M}(\sim 1 \%)$ perchlorate appears to be widespread among bacteria from hypersaline environments. Nearly all of the salinotolerant bacterial isolates examined grew, not only in the presence $0.1 \mathrm{M}$ perchlorate salts, but also at $0.5 \mathrm{M}(\sim 5 \%)$, and some grew at $1.0 \mathrm{M}(\sim 10 \%)$. Only Durand (1938) has demonstrated bacterial growth at such high perchlorate concentrations. Furthermore, we have demonstrated bacterial growth at concentrations of chlorate up to $2.75 \mathrm{M}(\sim 25 \%)$, where previous tolerance studies have not included chlorate salts.

Soils near the Phoenix lander appear to contain $\sim 0.4-0.6 \%$ (per)chlorate salts. If this was evenly distributed in the soil and then incorporated into liquid brine, the bacteria in our study could easily tolerate that level of (per)chlorate. However, it is likely that (per)chlorate salts exist as distinct phases within the soil. These hygroscopic salts may form heavy brines through deliquescence. Hence, the effective concentrations of (per) chlorate salts in solution would be much higher than the $0.6 \%$ (per)chlorate observed in bulk soil. Strong arguments can be made that (per)chlorate brines are some of the most likely sources of liquid water on Mars (Zorzano et al. 2009; Davila et al. 2010). In our study, the highest perchlorate concentration that allowed bacterial growth was $10 \%$. This is far lower than the eutectic concentrations of perchlorate salts. For instance, $\mathrm{Na}$ perchlorate has its eutectic point at $52 \mathrm{wt} \%$ at $-37^{\circ} \mathrm{C}$, while the eutectic point of $\mathrm{Mg}$ perchlorate is $44 \mathrm{wt} \%$ at $-67^{\circ} \mathrm{C}$ (Chevrier et al. 2009). It is possible that certain bacteria, perhaps those adapted to an environment high in perchlorate, are capable of growth at higher concentrations of perchlorate than observed in our study. Survival of viable cells likely occurs at higher (per)chlorate concentrations than growth. The great degree of chlorate tolerance we observed, with growth above $25 \%$ chlorate, is closer to what would be needed to grow in a eutectic solution of $\mathrm{Na}$ chlorate $\left(39 \mathrm{wt} \%\right.$ at $-23^{\circ} \mathrm{C}$ ) (Hanley et al. 2012). Note that the eutectic point for $\mathrm{K}$ chlorate is $3 \mathrm{wt} \%$ at $-3^{\circ} \mathrm{C}$ and well within the growth tolerances observed for $\mathrm{K}$ chlorate among our isolates.

Tolerance to chlorate salts was greater than tolerance to perchlorate salts by a wide margin. Limited growth in perchlorate salts was not solely due to cation effects, since all of the isolates can grow at concentrations of $\mathrm{NaCl}$ and $\mathrm{MgSO}_{4}$ above $1.0 \mathrm{M}$. At $2.75 \mathrm{M} \mathrm{Na}$ chlorate, however, $\mathrm{Na}$ concentrations are reaching the $\mathrm{Na}$ tolerance limits of even these salinotolerant microbes. Of the isolates in our study, only HL 11, 20 and 54 have been shown to grow above $20 \% \mathrm{NaCl}$ (Kilmer et al. 2014). Inhibition of the growth of HL91 above $1.5 \mathrm{M}(\sim 15 \%) \mathrm{Na}$ chlorate for example may have been due to cation effects, since this organism tolerates $10 \%(1.7 \mathrm{M}) \mathrm{NaCl}$, but not $20 \%(3.4 \mathrm{M})$ 
$\mathrm{NaCl}$. While growth of these isolates occurs in $\geq 50 \%(\sim 2 \mathrm{M})$ $\mathrm{MgSO}_{4}$, growth in $\mathrm{Mg}$ perchlorate was inhibited at much lower $\mathrm{Mg}$ concentrations (Crisler et al. 2012). Growth in relatively high concentrations of $\mathrm{Mg}$ chlorate may be possible, however, that salt could not be obtained commercially. Strong growth was observed with $\mathrm{K}$ perchlorate addition, best seen for isolates that were less tolerant overall. For instance, HL 54 and 82 were particularly sensitive to (per)chlorate salts, with HL82 unable to grow at even $0.1 \mathrm{M} \mathrm{Na}$ perchlorate. However, these isolates grew strongly in $1.0 \mathrm{M} \mathrm{K}$ perchlorate. Isolates most tolerant to perchlorate seemed to mirror those most tolerant to chlorate, suggesting a common mechanism for growth inhibition.

The observation of high (per)chlorate tolerance in salinotolerant bacteria demonstrates that terrestrial microbes are capable of growing at concentrations of (per)chlorate salts found in Mars soils. However, one of the most likely sources of bacteria that contaminate spacecraft is common oligosaline soil from around the SAF (Foster \& Winans 1975; Puleo et al. 1977). Common soils appear to harbour bacteria capable of growing at relatively high concentrations of salts and this is a concern for forward planetary protection (Echigo et al. 2005; Chen et al. 2010). Initial microbial abundance measurements by most probable number analysis of oligosaline turf soils found that $1.7 \times 10^{5}$ and $7.1 \times 10^{3}$ cells $\mathrm{g}^{-1}$ soil were tolerant to 10 and $20 \% \mathrm{NaCl}$, respectively (Kilmer et al. 2010; Porazka et al. 2011). Similarly, preliminary measurements of the abundance of bacteria tolerant to (per)chlorate salts indicate that it is not rare to find microbes that are tolerant to concentrations of (per)chlorate salts relevant to Mars (Crisler et al. 2013a, b; Al Soudi et al. 2016). While our salinotolerant isolates are from rare extreme environments, some of the bacterial species isolated from SAFs match those from hypersaline environments (Caton et al. 2004; Moissl et al. 2008; Stieglmeier et al. 2009). The cleanrooms that act as SAFs are dry environments $(\leq 40 \%$ relative humidity) and it has been shown that salinotolerant microbes are present on surfaces and perhaps enriched by selection (Venkateswaran et al. 2001, 2003a, b; La Duc et al. 2003; Link et al. 2003; Kempf et al. 2005). It will be interesting to directly test microbial isolates from SAFs and neighbouring soils for (per)chlorate tolerance.

\section{Acknowledgements}

The authors are grateful for the contributions of Zonaira Ahmad, Todd Caton, James Crisler, Timothy Eberl, Joshua Fleming, Sascha Khan, Brian Kilmer, Tony Mai, Hieu Nguyen, Anastasiya Nosova and Noah Schneegurt. We thank Fadi Aramouni for determining water activities and Anna Engelbrektson and John Coates for measuring (per)chlorate concentrations. Preliminary accounts of this work have been presented previously and abstracted (Mai et al. 2012; Crisler et al. 2013a, b; Al Soudi et al. 2016). This work was supported by awards from NASA ROSES Planetary Protection Research (09-PPR09-0004 and 14-PPR14-2-0002) and Kansas INBRE IDeA NIGMS NIH (P20 GM103418).

\section{References}

Al Soudi, A., Farhat, O., Chen, F., Clark, B.C. \& Schneegurt, M.A. (2016). Bacterial growth tolerance to chlorate and perchlorate salts relevant to Mars. In The 116th Annual Meeting of the American Society for Microbiology. Abstract No. FR-027.

Bardiya, N. \& Bae, J.-H. (2005). Bioremediation potential of a perchlorate-enriched sewage sludge consortium. Chemosphere 58, 83-90.

Carlström, C.I., Loutey, D.E., Wang, O., Engelbrektson, A., Clark, I., Lucas, L.N., Somasekhar, P.Y. \& Coates, J.D. (2015). Phenotypic and genotypic description of Sedimenticola selenatireducens strain CUZ, a marine (per)chlorate-respiring Gammaproteobacterium, and its close relative the chlorate-respiring Sedimenticola strain NSS. Appl. Environ. Microbiol. 81, 2717-2726.

Caton, T.M., Witte, L.R., Ngyuen, H.D., Buchheim, J.A., Buchheim, M.A. \& Schneegurt, M.A. (2004). Halotolerant aerobic heterotrophic bacteria from the Great Salt Plains of Oklahoma. Microb. Ecol. 48, 449462.

Chen, Q., Liu, Z., Peng, Q., Huang, K., He, J., Zhang, L., Li, W. \& Chen, Y. (2010). Diversity of halophilic and halotolerant bacteria isolated from non-saline soil collected from Xiaoxi National Natural Reserve, Hunan Province. Acta Microbiol. Sin. 50, 1452-1459. [Chinese].

Chevrier, V.F., Hanley, J. \& Altheide, T.S. (2009). Stability of perchlorate hydrates and their liquid solutions at the Phoenix landing site, Mars. Geophys. Res. Lett. 36, L10202.

Clark, B.C. \& Kounaves, S.P. (2015). Evidence for the distribution of perchlorates on Mars. Int. J. Astrobiol. doi: http://dx.doi.org/10.1017/ S1473550415000385.

Coates, J.D. \& Achenbach, L.A. (2004). Microbial perchlorate reduction: rocket-fueled metabolism. Nat. Rev. 2, 569-580.

Coates, J.D., Michaelidou, U., Bruce, R.A., O'Connor, S.M., Crespi, J.N. \& Achenbach, L.A. (1999). Ubiquity and diversity of dissimilatory (per) chlorate-reducing bacteria. Appl. Environ. Microbiol. 65, 5234-5241.

Crisler, J.D., Newville, T.M., Chen, F., Clark, B.C. \& Schneegurt, M.A. (2012). Bacterial growth at the high concentrations of magnesium sulfate found in Martian soils. Astrobiology 12, 98-106.

Crisler, J.D., Mai, T.T., Ahmad, Z., Chen, F., Clark, B.C. \& Schneegurt, M. A. (2013a). Bacterial growth at high concentrations of deliquescent salts potentially relevant to Mars. In The 145th Annual Meeting of the Kansas Academy of Science. Trans. KS Acad. Sci. 116, 71.

Crisler, J.D., Mai, T.T., Ahmad, Z., Chen, F., Clark, B.C. \& Schneegurt, M. A. (2013b). Bacterial growth in deliquescent lithium and perchlorate salts potentially relevant to Mars. In The 113th General Meeting of the American Society for Microbiology. Abstract No. 1053.

Davila, A.F. et al. (2010). Hygroscopic salts and the potential for life on Mars. Astrobiology 10, 617-628.

Durand, M.J. (1938). Recherches sur l'élimination des perchlorates, sur leur répartition dans les organes et sur leur toxicité. Bull. Soc. Chim. Biol. 20, 423-433. [French].

Echigo, A., Hino, M., Fukushima, T., Mizuki, T., Kamekura, M. \& Usami, R. (2005). Endospores of halophilic bacteria of the family Bacillaceae isolated from non-saline Japanese soil may be transported by Kosa event (Asian dust storm). Saline Syst. 1, 8. doi: 10.1186/1746-1448-1-8.

EPA (2011). Drinking water: regulatory determination on perchlorate. Fed. Regist. 76, 7762-7767.

Ericksen, G.E. (1981). Geology and Origin of the Chilean Nitrate Deposits. Geological Survey Professional Paper 1188, U.S. Government Printing Office, Washington.

Foster, T.L. \& Winans, L. (1975). Psychrophilic microorganisms from areas associated with the Viking spacecraft. Appl. Microbiol. 30, 546-550.

Glavin, D.P. et al. (2013). Evidence for perchlorates and the origin of chlorinated hydrocarbons detected by SAM at the Rocknest aeolian deposit in Gale crater. J. Geophys. Res. Planets 118, 1955-1973.

Gu, B., Dong, W., Brown, G.M. \& Cole, D.R. (2003). Complete degradation of perchlorate in ferric chloride and hydrochloric acid under controlled temperature and pressure. Environ. Sci. Technol. 37, 2291-2295.

Hanley, J., Chevrier, V.F., Berget, D.J. \& Adams, R.D. (2012). Chlorate salts and solutions on Mars. Geophys. Res. Lett. 39, L08201. 
Hecht, M.H. et al. (2009). Detection of perchlorate and the soluble chemistry of Martian soil at the Phoenix lander site. Science 325, 64-67.

Herman, D.C. \& Frankenberger, W.T., Jr. (1999). Bacterial reduction of perchlorate and nitrate in water. J. Environ. Qual. 28, 1018-1024.

Hooth, M.J., DeAngelo, A.B., George, M.H., Gaillard, E.T., Travlos, G.S., Boorman, G.A. \& Wolf, D.C. (2001). Subchronic sodium chlorate exposure in drinking water results in a concentration-dependent increase in rat thyroid follicular cell hyperplasia. Toxicol. Pathol. 29, 250-259.

Jackson, W.A. et al. (2015a). Global patterns and environmental controls of perchlorate and nitrate co-occurrence in arid and semi-arid environments. Geochim. Cosmochim. Acta 164, 502-522.

Jackson, W.A., Davila, A.F., Sears, D.W., Coates, J.D., McKay, C.P., Brundrett, M., Estrada, N. \& Böhlke, J.K. (2015b). Widespread occurrence of (per)chlorate in the Solar System. Earth Planet. Sci. Lett. 430, 470-476.

Kalkhoff, S.J., Stetson, S.J., Lund, K.D., Wanty, B.B. \& Linder, G.L. (2010). Perchlorate data for streams and groundwater in selected areas of the United States, 2004. U.S. Geological Survey Data Ser. 495, 43 pp.

Kempf, M.J., Chen, F., Kern, R. \& Venkateswaran, K. (2005). Recurrent isolation of hydrogen peroxide-resistant spores of Bacillus pumulis from a spacecraft assembly facility. Astrobiology 5, 391-405.

Kilmer, B.R., Chambers, C.A., Akbar, R., Bhakta, S., Beck, A., Brimmerman, J., Lundin, H., DeVries, C., Kasten, L., Pringle-Johnson, B., Ruder, J.S. \& Schneegurt, M.A. (2010). Isolation and characterization of halotolerant bacteria from inland oligohaline soils. In The 110th General Meeting of the American Society for Microbiology. Abstract No. 298.

Kilmer, B.R., Eberl, T.C., Cunderla, B., Chen, F., Clark, B.C. \& Schneegurt, M.A. (2014). Molecular and phenetic characterization of the bacterial assemblage of Hot Lake, WA, an environment with high concentrations of magnesium sulphate, and its relevance to Mars. Int. J. Astrobiol. 13, 69-80.

Kounaves, S.P. et al. (2010). Wet chemistry experiments on the 2007 Phoenix Mars Scout Lander mission: data analysis and results. J. Geophys. Res. 115, E00E10.

Kounaves, S.P., Carrier, B.L., O’Neil, G.D., Stroble, S.T. \& Claire, M.W. (2014). Evidence of Martian perchlorate, chlorate, and nitrate in Mars meteorite EETA79001: implications for oxidants and organics. Icarus 229, 206-213.

Kral, T.A., Goodhart, T.H., Harpool, J.D., Hearnsberger, C.E., McCracken, G.L. \& McSpadden, S.W. (2016). Sensitivity and adaptability of methanogens to perchlorates: implications for life on Mars. Planet Space Sci. 120, 87-95.

La Duc, M.T., Nicholson, W., Kern, R. \& Venkateswaran, K. (2003). Microbial characterization of the Mars Odyssey spacecraft and its encapsulation facility. Environ. Microbiol. 5, 977-985.

Link, L., Sawyer, J., Venkateswaran, K. \& Nicholson, W. (2003). Extreme spore UV resistance of Bacillus pumulis isolates obtained from ultraclean spacecraft assembly facility. Microb. Ecol. 47, 159-163.

Mai, T.T., Nosova, A.O. \& Schneegurt, M.A. (2012). Bacterial growth in perchlorate salts at concentrations found in soils on Mars. In 144th Annual Meeting of the Kansas Academy of Science. Trans. KS Acad. Sci. 115, 64.

Martín-Torres, F.J. et al. (2015). Transient liquid water and water activity at Gale crater on Mars. Nat. Geosci. 8, 357-361.

Ming, D.W. et al. (2014). Volatile and organic compositions of sedimentary rocks in Yellowknife Bay, Gale Crater, Mars. Science 343. doi: 10.1126/ science. 1245267.

Möhlmann, D. \& Thomsen, K. (2011). Properties of cryobrines on Mars. Icarus 212, 123-130.

Moissl, C., Bruckner, J.C. \& Venkateswaran, K. (2008). Archaeal diversity analysis of spacecraft assembly clean rooms. ISME J. 2, 115-119.

Motzer, W.E. (2001). Perchlorate. Problems, detection, and solutions. Environ. Forensics 2, 301-311.

Nuding, D.L. et al. (2014). Deliquescence and efflorescence of calcium perchlorate: an investigation of stable aqueous solutions relevant to Mars. Icarus 243, 420-428.
Ojha, L., Wilhelm, M.B., Murchie, S.L., McEwen, A.S., Wray, J.J., Hanley, J., Massé, M. \& Chojnacki, M. (2015). Spectral evidence for hydrated salts in recurring slope lineae on Mars. Nat. Geosci. 8, 828-832.

Okeke, B.C., Giblin, T. \& Frankenberger, W.T., Jr. (2002). Reduction of perchlorate and nitrate by salt tolerant bacteria. Environ. Pollut. 118, 357-363.

Oren, A., Bardavid, R.E. \& Mana, L. (2014). Perchlorate and halophilic prokaryotes: implications for possible halophilic life on Mars. Extremophiles 18, 75-80.

Porazka, T., Kilmer, B.R., Wichita High School Northwest Team, Wichita Northeast Magnet High School Team \& Schneegurt, M.A. (2011). Inland oligohaline soils as a habitat for culturable halotolerant bacteria. In 143rd Annual Meeting of the Kansas Academy of Science. Trans. KS Acad. Sci. 115, 170.

Puelo, J.R., Fields, N.D., Bergstrom, S.L., Oxborrow, G.S., Stabekis, P.D. \& Koukol, R. (1977). Microbiological profiles of the Viking spacecraft. Appl. Environ. Microbiol. 33, 379-384.

Rajagopalan, S., Anderson, T.A., Fahlquist, L., Rainwater, K.A., Ridley, M. \& Jackson, W.A. (2006). Widespread presence of naturally occurring perchlorate in high plains of Texas and New Mexico. Environ. Sci. Technol. 40, 3156-3162.

Rajagopalan, S., Anderson, T., Cox, S., Harvey, G., Cheng, Q. \& Jackson, W.A. (2009). Perchlorate in wet deposition across North America. Environ. Sci. Technol. 43, 616-622.

Rao, B., Anderson, T.A., Orris, G.J., Rainwater, K.A., Rajagopalan, S., Sandvig, R.M., Scanlon, B.R., Stonestrom, D.A., Walvoord, M.A. \& Jackson, W.A. (2007). Widespread natural perchlorate in unsaturated zones in the Southwest United States. Environ. Sci. Technol. 41, 4522-4528.

Shcherbakova, V., Oshurkova, V. \& Yoshimura, Y. (2015). The effects of perchlorates on the permafrost methanogens: implication for autotrophic life on Mars. Microorganisms 3, 518-534.

Shete, A., Mukhopadhyaya, P.N., Acharya, A., Aich, B.A., Joshi, S. \& Gholem, V.S. (2008). Aerobic reduction of perchlorate by bacteria isolated in Kerala, South India. J. Appl. Genet. 49, 425-431.

Smith, P.N., Yu, L., McMurry, S.T. \& Anderson, T.A. (2004). Perchlorate in water, soil, vegetation, and rodents collected from the Las Vegas Wash, Nevada, USA. Environ. Pollut. 132, 121-127.

Stieglmeier, E., Wirth, R., Kminek, G. \& Moissl-Eichinger, C. (2009). Cultivation of anaerobic and facultatively anaerobic bacteria from spacecraft-associated clean rooms. Appl. Environ. Microbiol. 75, 3483-3491.

Thombre, R.S., Oke, R.S., Dhar, S. \& Shouche, Y. (2015). Survival of haloarchaea in high concentration of perchlorate - Significant requirement for survival on Mars. In The Astrobiology Science Conf., Chicago. Abstract No. 7080.

Urbansky, E.T. (1998). Perchlorate chemistry: implications for analysis and remediation. Bioremed. J. 2, 81-95.

Urbansky, E.T. (2002). Perchlorate as an environmental contaminant. Environ. Sci. Pollut. Res. 9, 187-192.

Venkateswaran, K., Satomi, M., Chung, R., Koukol, R., Basic, C. \& White, D. (2001). Molecular microbial diversity of a spacecraft assembly facility. Syst. Appl. Microbiol. 24, 311-320.

Venkateswaran, K., Kempf, M., Chen, F., Satomi, M., Nicholson, W. \& Kern, R. (2003a). Bacillus nealsonii sp. nov., isolated from a spacecraft assembly facility, whose spores are gamma-radiation resistant. Int. J. Syst. Evol. Microbiol. 53, 165-172.

Venkateswaran, K., Hattori, N., La Duc, M.T. \& Kern, R. (2003b). ATP as a biomarker of viable microorganisms in clean-room facilities. J. Microbiol. Methods 52, 367-377.

Wallace, W., Ward, T., Breen, A. \& Attaway, H. (1996). Identification of an anaerobic bacterium which reduces perchlorate and chlorate as Wolinella succinogenes. J. Ind. Microbiol. 16, 68-72.

Wallace, W., Beshear, S., Williams, D., Hospadar, S. \& Owens, M. (1998). Perchlorate reduction by a mixed culture in an up-flow anaerobic fixed bed reactor. J. Ind. Microbiol. Biotechnol. 20, 126-131.

Zorzano, M.-P., Mateo-Martí, E., Prieto-Ballesteros, O., Osuna, S. \& Renno, N. (2009). Stability of liquid saline water on present day Mars. Geophys. Res. Lett. 36, L20201. 